\title{
EQUiLIBRIUM
}

Quarterly Journal of Economics and Economic Policy

2016 VOLUME 11 ISSUE 3, September

p-ISSN 1689-765X, e-ISSN 2353-3293

www.economic-policy.pl

Lewandowski, R. (2016). Economic Sectors of Strategic Importance to the National Security. A Case of Poland. Equilibrium. Quarterly Journal of Economics and Economic Policy, 11(3), 473-497. DOI: http://dx.doi.org/10.12775/EQUIL.2016.022

Remigiusz Lewandowski*

Nicolaus Copernicus University, Poland

\section{Economic Sectors of Strategic Importance to the National Security. A Case of Poland}

JEL Classification: $F 52 ; H 13 ; H 56$

Keywords: strategic sectors; national security

\begin{abstract}
The purpose of the paper is to properly define the economic sectors of strategic importance to the national security and to evaluate the state's tools which protect this security. The paper's methodology is based on two analyses; the former focusing on instruments which are applied by the state in order to control certain fields of the economy, and the latter investigating economic sectors in terms of concentration, impact on the state security and integration with other sectors. The paper also defines the criteria which helped to identify sectors which have strategic importance to the national security, i.e. production and supply of electric energy; extraction and supply of natural gas; extraction, distribution and storage of liquid propellants, telecommunications, banking industry; banknotes and documents' production (together with related IT solutions) and military industry. The article leads to the conclusion that these sectors are strategically important to the national security. However, there is still a lack of coherent and complete legal regulations that would protect the national security interest related to the part of the economy represented by the analyzed sectors and companies.
\end{abstract}

(C) Copyright Institute of Economic Research

Date of submission: May 12, 2015; date of acceptance: June 6, 2016

* Contact: rlewandowski@umk.pl, Wydział Nauk Ekonomicznych i Zarządzania UMK w Toruniu, ul. Gagarina 13a, 87-100 Toruń, Poland 


\section{Introduction}

One of the most important elements of the academic debate on the state's role in the economy is the question of its activity as a shareholder (owner) of given businesses. The literature review shows that there are two mainstreams of analyzing the state's activity as a shareholder. The first one focuses on strategic management, whereas the latter covers the issues of political economy. These mainstreams represent a different approach to conditions of the state's direct economic activity and the competitiveness of the economy. In this context, the research in the field of strategic management concentrates on an enterprise itself (and the market on which it acts) and its specific attributes as factors that define its competitive advantage, such as available resources, the firm's position, market attractiveness, strategic directions or corporate strategies (e.g. Barney \& Zajac, 1994, pp. 5-9, O'Sullivan, 2000, pp. 393-416). On the other hand, research covering the questions of economic policy emphasizes the role of the state apparatus in the process of building competitive advantages on the level of the country, branches and individual firms (e.g. Hall \& Soskice, 2001, pp. 1-68). A very comprehensive field of empirical research is given by case studies of the so-called Asian tigers, i.e. Japan, South Korea, Taiwan and China (e.g. Matthews, 2002, pp. 633-652; Amsden, 2001). This research mainly focuses on the phenomenon of rapid economic growth, industrialization based on high technologies, as well as the reasons for the Asian crisis and its effect in respect to the economic policies carried out by the governments of these countries. Undoubtedly, the state's engagement in the economy was a crucial factor in the dynamic growth of the mentioned group of countries. For example, it was justified to call - until the end of the 1990s - an economic system of Japan "a governed market economy of the Keynesian type" (Samaryna, 2010, p. 48). The degree of the state's engagement has been evolving, which was clearly visible just after the Asian crisis. Nonetheless, the focus on innovations and the state's assistance in building the innovative industry was a constant motive of economic policy. Such an activity has not been exclusively reserved for Asian countries. The history of firms such as Airbus/EADS or Embraer confirms the direct role of the state (also as a shareholder) in creating innovative branches in Europe and South America. Moreover, according to Olszewski (2012, p. 551), "an analysis of privatizations carried out in Ireland in the period from 1991 has made some experts dealing with the effects of corporate management before and after privatization make an argument that it is necessary to remain a state control over firms in the strategic sectors". 
Other academic research into this issue mainly concentrated on the issue of innovations or - in the broader context - on the issue of competitive advantage at an international level and/or in branches that are strategically important for the development of the analyzed countries. National business champions are a good example of such a question discussed both by academics and politicians (Lewandowski, 2014a, pp. 767-783).

The state's activity in the branches of strategic importance to the national security is a relatively rare subject of academic debate. However, the national security is one of the strategic objectives of the state. According to Kitler (2011, p. 27), it is "a primary value among other (national) objectives of the state and at the same time it decides whether they are met." Therefore, this paper attempts to fill a gap in the literature and answer questions on a definition of branches of strategic importance to the national security as well as point out their functions on the example of the sector of banknotes and documents' production.

\section{Research Methodology}

The aim of this paper is to properly define the economic sectors of strategic importance to the national security and to evaluate the instruments used by the state in order to protect the aforesaid security. In the research the following methodology has been used:

- an analysis of legal regulations, especially referring to the state's instruments in the field of control over selected parts of the economy,

- an analysis of economic sectors with respect to: their concentration, their effect on the national security and their integration with other sectors.

While defining the sectors of strategic importance to the national security it was necessary to find criteria classifying whether the discussed sectors are or are not strategic. There are two such criteria used in this paper:

- running a business which directly satisfies the needs of the national security or

- a high degree of integration of a given sector with other sectors or with subsistence needs of the society (a high relationship), and a simultaneous high degree of concentration of the given sector.

The level of concentration was measured with commonly used measures, such as a Herfindahl-Hirschman Index (HHI) and a Concentration Ratio $(\mathrm{CR}(\mathrm{N}))$. Moreover, a literature analysis supported each aspect of the analyzed issues. 


\section{Regulatory Tools}

The state has at its disposal a range of tools which allow to directly affect firms, whose activity, for many reasons, remains important for the state. This type of the state's control over selected companies is out of the question and is an element of the national security system ${ }^{1}$. The typical tools in this respect cover:

- involvement of the state in the shareholders structure of companies (direct and indirect),

- golden share (or golden veto) or special rights of the Minister of Treasury with respect to legal actions of selected companies,

- special regulations imposing tasks related to the national security on selected entrepreneurs,

- regulations governing activities of selected economic sectors,

- regulations governing public procurement,

- regulations governing control over investments in selected economic sectors.

The first, most important tool at the state's disposal affecting companies of strategic importance to the national security is the execution of the state's ownership rights. This type of the state's economic activity does not violate the rules of the market economy and the role of the private sector.

The direct ownership governance covering complete or partial control of the state over companies equity is the strongest tool ensuring the protection of the key interests of the state security which are related to the activities of these companies. As both the practice and research show, if such state's involvement in equity is properly limited to companies which in fact require such control, it not only does not bring any economic disadvantages, but actually generates value added to the shareholder, i.e. to the Treasury (Lewandowski, 2014a, pp. 770-782; Zahariadis, 1998, p. 460). The state's involvement in equity enables the state to execute its goals by the power of voting rights in corporate bodies. Moreover, the state guarantees its position in some public companies by special rights adopted in articles of association. For instance, in Grupa Azoty or PGE the articles of association limit (regardless of the amount of shares) the power of voting rights of shareholders other than the Treasury. This limit equals to $20 \%$ in Grupa Azoty and $10 \%$ in PGE. Such regulations help to protect the companies against a hostile takeover.

\footnotetext{
${ }^{1}$ For example, ,,it is necessary to remain the state's control over the key infrastructure of the fuel and energy sector as well as extend the control and governance over the geological resources of the country." (Strategia Bezpieczeństwa..., 2014, p. 55).
} 
The notion of a golden share (or a golden veto) is quite often used in business practice on capital markets. This notion is not defined in Polish legislation. In the literature, the notion of a golden share is usually understood as shares which give their holder special rights (Dziawgo, 2007, p. 100 ), much broader than the rights attached to preference shares (with respect to votes, dividends and a priority on return of capital on a windingup) defined by the Code of Commercial Partnerships and Companies. The mentioned broader, extra rights related to a golden share may refer to two areas (Knurowska, 2000, p. 74):

- a possibility of a protest against particular resolutions of the general meeting, regardless of the number of votes attached to the golden share,

- a guarantee of a specified amount of dividends to the holder of a golden share, regardless of the financial result made in a given accounting period.

The Polish law does not envision such defined shareholders rights, including rights of the Treasury. They were abolished in 2010 together with the act of Parliament of $3^{\text {rd }}$ June, 2005, on special rights of the Treasury and their execution in commercial companies of a significant importance to the public order or public safety ${ }^{2}$. Nonetheless, some analogous rights of the Treasury are defined in the act of parliament of March $18^{\text {th }}, 2010$, on special rights of the minister responsible for the Treasury and their execution in some commercial companies or holdings in the sectors of electric energy, as well as liquid and gaseous fuel ${ }^{3}$.These rights constitute the third group of the state's control over companies. The act refers to companies doing business in the areas pointed out above and whose assets have been included in the uniform register of objects, installations, equipment and services composing the Critical Infrastructure (CI). Therefore, the discussed rights refer not only to companies partly or fully owned by the Treasury but also to firms from the private sector. The act empowers the minister of Treasury to protest against:

- a resolution (or other legal action) passed by the management board which refers to a disposal of assets constituting CI and which poses a realistic risk for functioning, business continuity and integrity of $\mathrm{CI}$;

- a resolution passed by corporate bodies which refers, inter alia, to a disposal of corporate assets and their utilization, the scope of the business and the registered office - if an execution of such a resolution posed a realistic risk on functioning, business continuity and integrity of CI.

\footnotetext{
${ }^{2}$ Dziennik Ustaw of 2005, No. 132, item 1108, as amended.

${ }^{3}$ Dziennik Ustaw of 2010, No. 65, item 404.
} 
From the point of view of the national security, the influence power of the discussed rights on companies' operations is rather modest. Firstly, it is a consequence of a limited number of companies affected by the act (a small subjective scope). It refers only to firms coming from the sectors of electric energy, as well as liquid and gaseous fuel. Secondly, it results from a narrow objective scope of the rights which are limited only to legal actions which may bring a threat to functioning, business continuity and integrity of CI. Accordingly, a number of other types of legal actions (not related to $\mathrm{CI}$ ) of significant importance to the national security are omitted. For instance, this veto power does not cover a commercial policy referring to suppliers of energy sources ${ }^{4}$ or an investment policy referring to new infrastructure ${ }^{5}$.

Apart from the presented above instrument of a veto, there are legal regulations that impose tasks related to the national security on selected entrepreneurs. They constitute the third group of tools which enable the state to affect given firms. These tasks cover, inter alia:

- an obligation to protect objects, installations and equipment of CI by their owners,

- the economy mobilization, militarization, operational planning, defense training and tasks resulting from the obligations of the host states.

Companies which possess IC are listed in the uniform register of objects, installations, equipment and services composing the Critical Infrastructure $(\mathrm{CI})$. The registry is secret (article $5 \mathrm{~b}$, paragraph 7 , point 1 ). In turn, the registry of companies doing tasks related to defense is included in the Regulation of the Council of Ministers of October $4^{\text {th }}, 2010$, on the registry of entrepreneurs of special economic and defense significance. The scope of these tasks is limited to protection of CI and tasks related to defense and military security.

The fourth group of discussed tools are legal acts regulating selected sectors of the economy. The regulatory function of the state refers to many sectors. According to the theory of economic regulation, based on a concept of a public interest, the market is inefficient or inequitable and it never, without corrections, leads to an efficient allocation of resources in the economy (Nagaj, 2012). Therefore, the state willing to maximize wealth decides to regulate the market in order to minimize the inefficiency and its negative consequences on the economy. The correction of resource allocation which is done through market regulation also covers minimizing the risks of national security violation in the field shaped by business opera-

\footnotetext{
${ }^{4}$ For instance it refers to supply diversification of crude oil and natural gas.

${ }^{5}$ See, e.g., the case of a new power unit in Opole planned to be built by PGE SA in 2013.
} 
tions. The key fields of such a state's regulation cover the price level, quality, service provision conditions (including temporary sale limitations ${ }^{6}$ ) and licensing (Kahn, 1998).

The clearest examples of the regulated sectors are those which are controlled by special watchdogs, i.e. sectors belonging to the financial market (Commission of Financial Supervisory), telecommunication market (Office of Electronic Communications) and the energy market (Energy Regulatory Office). Additionally, the Office of Consumer and Competition Protection is responsible for the proper market structure in all the sectors. Moreover, in respect to some markets the regulation is ensured on the EU level. Agriculture is an example of such a specially regulated market, subordinated to the Common Agriculture Policy as well as specific EU and domestic legal regulations. It is worthwhile to say that sectors described above are just examples of the markets regulated by the state. The range of regulation in terms of sectors is very broad and the intensity of regulation differs. In Polish domestic legislation there are more than 20 acts which define selected types of activities as regulated operations and specifically describe their conditions (Łagowska, 2012, p. 145).

Licensing, among instruments of regulation the most important, at least from the national security's point of view, is one of the most important tools. The fundamental reason justifying the use of licensing is the national security, including protection of citizens' interests and protection of economic interests of the state (Kosikowski, 2007, p. 187). The act of July $2^{\text {nd }}$, 2004 , on business freedom ${ }^{7}$, lists 8 areas of businesses which require a license from the state:

- searching and recognizing of motherlodes of hydrocarbons, minerals as well as objects of underground storage of carbon dioxide, exploiting of minerals, underground storage of waste, underground and underground storage of carbon dioxide;

- production and sales of explosives, arms and ammunition as well as products and technologies dedicated to be used by the army or police;

- production, processing, storage, transfer, distribution and sales of fuel and energy;

- carbon dioxide transfer related to its underground storage;

- protection of people and property;

- radio and TV broadcasting;

\footnotetext{
${ }^{6}$ For example, the act of Parliament on Energy Law in article 11 allows to temporally limit the sales of solid fuel as well as distribution and consumption of electrical energy or heat in case of a threat of energy security of Poland.

${ }^{7}$ Article 46, paragraph 1, Dziennik Ustaw of 2004, No. 173, item 1807, as amended
} 
- air transport;

- gambling business.

It is not clear why production of public documents and currency is not included in the above list. In many EU member states such a business is licensed.

The act of January $29^{\text {th }}, 2004$, on Public Procurement Law ${ }^{8}$, is a significant instrument of affecting selected companies or sectors by the state. According to this act, the state has a right to use a special procedure of placing an order, i.e. with an exclusion of the Public Procurement Law regulations. This exclusion is related to procurement concerning the national security, and, inter alias, it covers:

- procurements of currency, made by the National Bank of Poland;

- procurements that are „secret” or „top secret" in accordance with the regulations on the protection of non-public information, if it is required by the material interest of state security or assurance of public safety;

- procurements related to production or sales of arms, ammunition or military equipment, if it required by the material interest of state security;

- procurements for the purposes of security and military protection in case the application of the act's regulations would obligate the contracting authority to share the information whose disclosure is contrary to the basic interests of state security;

- procurements for the purposes of security and military protection related to intelligence.

This discretionary power of the state which allows to freely choose a supplier protects the material interest of the state security. In particular, it helps to keep an information on what the subject of the state's security expenditures is, in confidentiality, as well as it insures that a relative stability of deliveries and provides that the economic interest of the state is realized (Flak, 2014, pp. 47-48). A lack of subject exclusions related to procurements of excise tax bands and public documents (such as identification documents, passports and other documents of significant importance to the national security) is a weakness of the Public Procurement Law.

Many countries try to find a compromise between privatization and the need of control (or restrictions) over foreign direct investments in sectors of strategic importance to the national security. French solutions in this respect are a good example of such control. A French decree ${ }^{9}$ lists those sectors which shall be protected from a takeover by foreign companies. The

\footnotetext{
${ }^{8}$ Dziennik Ustaw of 2004, No. 212, item 1387, as amended.

${ }^{9}$ Decree No. 2005-1739.
} 
list comprises, inter alia: businesses of dual nature (both military and civil), businesses related to cryptology, production and sales of arms and ammunition, business related to evaluation and certification of ICT products and services, businesses related to protection of the state's secrets (Olszewski, 2012, pp. 548-549). Similar legal regulations are introduced in Italy. The restrictions seem to be a natural choice from the point of view of the national security. A situation when a company which is a part of a sector of strategic importance to the national security is taken over by foreigners who cannot guarantee that this company will operate as before, generates a threat to the national security. In extreme cases, the situation may refer to takeovers which aim at eliminating the targeted company from the domestic market and making the economy dependent on foreign firms or paralyzing the economy. An attempt of a hostile takeover of a publicly traded company Grupa Azoty by Russian company Acron is an interesting case of such actions ${ }^{10}$.

The act of July $24^{\text {th }}, 2015$, on control over some investments ${ }^{11}$, is a new and relatively good instrument that limits the risk of loosing control over strategic sectors. According to the regulation, a domination over a protected company requires a prior consent of the minister of Treasury. However, the issue of a range of protected sectors is a drawback of the act. The list of sectors is not complete, that is, it does not cover all the sectors which are considered in this paper as strategic to the national security, e.g. production of public documents and currency is not included in the list.

The above analysis of the legal regulations and the current ownership strategy of the Treasury lead to the conclusion that there is no holistic perspective in Poland on companies and sectors of strategic importance to the national security. Such a perspective shall define the role of discussed companies and sectors as well as their objectives from the state's point of view and stabilize their position in the economy, and finally set up an optimal environment for their development. However, there is neither such a holistic perspective, nor a list of strategic companies, even limited to firms controlled by the treasury. It seems that the time-being fragmentary perception of the role of companies and sectors strategic to the national security and resulting atomization in this respect limiting the point of view to functions and objectives related to:

- military security,

- energy security,

- protection of CI.

${ }^{10}$ Retrieved from http://wiadomosci.onet.pl/tylko-w-onecie/rzad-vs-acron-trwa-walka-ogrupe-azoty/p4793 (03.03.2015).

${ }^{11}$ Dziennik Ustaw of 2015, item 1272, as amended. 
It is insufficient to ensure a proper protection of security and proper use of the national capacity of the economy. Although the National Security Strategy of Poland attempts to fulfil this evident gap and articulates some necessary actions in terms of economic policy, but definitely the strategic reflection of the document does not exhaust the issue. Therefore, it is necessary to identify the sectors which are strategic to the national security and prepare a clear vision of their role and development. This paper is the first step in this process.

\section{Classification Criteria}

The above paragraphs present the instruments which are controlled by the state and which enable it to affect companies or sectors of significant importance to the national security. Legal regulations in this respect do not precisely point out any sectors or companies that play a strategic role in the system of the national security. Neither are there any concrete criteria which would help to classify them correctly. However, it seems that such criteria are necessary in order to comprehensively manage companies of strategic importance to the national security and at the same time to fully make use of the tools that are available for the state.

The tools presented in the first part of the paper can be used in highlighting different types of companies which are crucial for the national security:

- state-owned companies of significant importance to the economy of the state (22 companies),

- entrepreneurs of economic and military significant importance (177 firms),

- companies operating CI (the register is secret).

The above types are constructed on the basis of different criteria and each of them is related to a different function in the national security system. As it was mentioned before, no legal act and no government document defines economic sectors that are strategically important to the national security. The notion "companies of strategic importance to the national security" should be understood as companies whose distorted business operations will significantly violate the national security. In this respect, a narrow meaning of the national security definition is used, i.e. it is the state of the legal and internal order in relation to maintaining the territory, survival of the nation and maintaining the independent authorities (Kitler, 2011, p. 29). The distortion of business operations refers in particular to 
continuity of supply, quality of produced goods (services) and confidentiality if it is necessary for the protection of the national security.

In order to list such companies it is necessary to precisely define classification criteria which will help to isolate sectors of strategic importance to the national security, and then, within the sectors, to isolate individual companies. Therefore, it is suggested to use the following criteria:

- the nature of the business directly satisfying the needs of the national security, or

- a high degree of integration of a given sector with other sectors of the economy or with subsistence needs of the society, and a simultaneously high degree of concentration of the sector.

The first criterion seems to be natural and evident. It covers those sectors which directly satisfy the objectives of the national security (in a narrow meaning) and directly satisfy the needs of the state in this respect. The business activity directly satisfying the national security needs of the state are:

- production of arms and ammunition,

- production of currency (mainly banknotes ${ }^{12}$ ),

- production of high security print-outs, identification documents and authorizing documents.

Among companies controlled by the Treasury there are two firms which fulfill the criteria. It is Polska Grupa Zbrojeniowa SA (together with its subsidiaries) which does the business pointed out in 1), as well as Polska Wytwórnia Papierów Wartościowych SA (PWPW SA), operating in 2) and $3)$. Possessing an efficient and innovative military industry is necessary in order to keep the continuity of arms and ammunition supply in case of a sudden threat of the national security. Maintaining the continuity of the government administration, including public order, requires unquestionable services in the field of citizens' identification and verification of their authorizations on the basis of documents and related IT. Currency, and banknotes in particular, is a basic means of transactions essential for the public order.

The second criterion is a conjunction of two factors: a degree of integration with other sectors (or with subsistence needs of the society) and a degree of concentration of the analyzed sector. The degree of integration informs how the disruption of operations of the given sector can affect other sectors (or society). So, the higher the degree of integration is, the greater its significance to the national security. However, the degree of integration cannot be treated as an exclusive indicator of significance to the na-

\footnotetext{
$1297 \%$ of the cash in the circulation is constituted by banknotes.
} 
tional security, because one must take into account also vulnerability of the given sector to disruptions, especially related to supply breaks. This vulnerability can be measured through the degree of concentration. The higher the degree is, the greater the risk of disruptions is. In case of sectors of low concentration, even a disruption of a large quantity of companies of insignificant market share will not affect the national security.

\section{Highly Integrated and Highly Concentrated Sectors}

For the purpose of this paper, the degree of integration of analyzed sectors was individually evaluated by the author. This approach results from the lack of instruments of objective classification in this respect. However, it would be worth developing scientific, objective measures of integration. It could be an interesting field of academic research. The concentration degree of analyzed sectors was evaluated with the Herfindahl-Hirschman Index (HHI) and the Concentration Ratio $(\mathrm{CR}(\mathrm{N}))$. For both criteria three types of degree were used: high, medium and low. Table 1 presents the results of classification limited to highly integrated sectors. In the analysis the Polish Classification of Operations (PKD) was used. The term "sector" was understood as a "group" in the meaning of PKD. In some cases it was necessary to form a new sector (not present in PKD), especially when the range of the "group" was too broad ${ }^{13}$.

As Table 1 shows, in Poland there are 6 sectors which are highly integrated and highly concentrated. These are:

- production and supply of electricity;

- extraction, transfer, distribution and storage of gaseous fuels;

- production, transfer, distribution and storage of liquid fuels;

- telecommunications;

- banking,

- banknotes and documents production.

The whole economy and subsistence needs of citizens are dependent on the energy industry. It refers to three fields of operations: production, transfer and distribution of energy. These three fields are highly concentrated. $\mathrm{CR}(3)$ for the market of energy production equals to $63 \%$. The three largest companies on this market are PGE (39\%), Tauron (14\%) and EDF

${ }^{13}$ For instance it refers to business operations on production of banknotes and documents, which according to PKD are classified to the groups: „18.1 Printing and services related to printing" and "62.0 Operations related to IT and IT consulting”. 
$(10 \%)^{14}$. The transfer of energy (without distribution) is monopolized by one operator, i.e. PSE.

Table 1. Highly integrated sectors and state-owned companies

\begin{tabular}{|c|c|c|c|c|}
\hline No. & Sector & $\begin{array}{l}\text { Degree of } \\
\text { integration }\end{array}$ & $\begin{array}{c}\text { Degree of } \\
\text { concentration }\end{array}$ & $\begin{array}{c}\text { State-owned } \\
\text { companies }\end{array}$ \\
\hline 1 & Agriculture & High & Low & - \\
\hline 2 & Hard coal mining & Medium & High & $\begin{array}{c}\text { Kompania Węglowa, } \\
\text { Jastrzębska Spółka } \\
\text { Węglowa, Katowicki } \\
\text { Holding Węglowy }\end{array}$ \\
\hline 3 & Food industry & High & Low & - \\
\hline 4 & Water supply & High & Low & - \\
\hline 5 & Healthcare & High & Low & - \\
\hline 6 & $\begin{array}{l}\text { Production and supply } \\
\text { of electricity }\end{array}$ & High & High & $\begin{array}{l}\text { PGE, Tauron, Energa, } \\
\text { Enea, PSE }\end{array}$ \\
\hline 7 & $\begin{array}{l}\text { Extraction, transfer, } \\
\text { distribution and storage } \\
\text { of gaseous fuels }\end{array}$ & High & High & PGNiG, Gaz-System \\
\hline 8 & $\begin{array}{l}\text { Production, transfer, } \\
\text { distribution and storage } \\
\text { of liquid fuels }\end{array}$ & High & High & Orlen, Lotos, PERN \\
\hline 9 & Chemical industry & High & Medium & Grupa Azoty \\
\hline 10 & Road transport & High & Low & - \\
\hline 11 & Telecommunication & High & High & - \\
\hline 12 & Banking & High & High & PKO BP, BOŚ, BGK \\
\hline 13 & $\begin{array}{l}\text { Banknotes and } \\
\text { documents production }\end{array}$ & High & High & PWPW \\
\hline
\end{tabular}

Source: own compilation.

$\mathrm{CR}(3)$ for the market of Energy distribution is $82 \%$, and the market is controlled by Tauron (40\%), PGE (26\%) and Energa (16\%) ${ }^{15}$.

Extraction and storage of gaseous fuels, as well as their distribution is practically monopolized by PGNiG, whose market share is $97 \%$ (PGNiG

14 Data for 2013. Retrieved form http://www.ure.gov.pl/pl/rynki-energii/energiaelektryczna/charakterystyka-rynku/5785,2013.html (03.03.2015).

${ }^{15}$ Data for 2011. (Strategia i model biznesowy..., 2012, p. 3). 
Annual Report, 2013, p. 57). This sector is also crucial for the economy and citizens. The distribution of gaseous fuels is monopolized by Gaz-System.

Extraction, transfer and storage of liquid fuels are of a key importance to the economy too. The subsector of wholesale distribution is dominated by two companies Orlen and Lotos, which altogether control $75 \%$ of the market ${ }^{16}$. The subsector of production (refining) firms control the whole domestic market, with Orlen's market share of 62\% and Lotos' - 38\%. Transfer and storage of crude oil in Poland is monopolized by PERN „Przyjaźń”.

The telecommunication was analyzed through subsectors of: operators of Internet, operators of mobile telephony, operators of fixed-line telephony and fibre-optic backbone networks. The transfer of information through the telecommunication network is indispensable to the maintenance of the state and the economy. In the market of Internet operators CR(3) equals to 50\%, which covers Orange (32\%), T-Mobile (10\%) and P4/Play (8\%) (Raport o stanie rynku..., 2014, pp. 10-11). In the mobile telephony $\mathrm{C}(4)$ equals to $98 \%$, which consists of Orange (27\%), T-Mobile (27\%), Polkomtel/Plus (25\%) and P4/Play (19\%) (Raport o stanie rynku..., 2014, pp. 26). The fixed-line telephony is dominated by three companies: Orange (57\%), Netia (11\%) and UPC (8\%). CR(3) is 76\% (Raport o stanie rynku..., 2014, p. 44). The fibre-optic backbone market is controlled by four firms: Orange (about 71\%), Exatel (about 18\%), TK Telekom (about 6\%) and Netia (about $5 \%)^{17}$. It is important to note that Exatel is fully controlled by PGE, whose $58 \%$ belongs to the Treasury. Similarly, TL Telekom is controlled by PKP SA, which belongs to the Treasury.

Banking is also a business of extreme significance to the economy. Any disruptions in this sector have an impact on the real economy. The Polish banking sector is highly concentrated. CR(4) equals to $52 \%{ }^{18}$. It is also a sector of high degree of foreign capital $-73 \%$ the banking assets (excluding cooperative banks) belong to foreign investors, whereas some economists argue that the ratio safe for the national economy is 30-35\% (Kawalec \& Gozdek, 2013, p. 48).

The last analyzed sector of high concentration and integration is production of banknotes and documents as well as related IT. The business in Poland is controlled by one company, PWPW SA, which is a natural monopoly.

16 Data for 2011. Retrieved form http://www.ure.gov.pl/pl/rynki-energii/paliwaciekle/charakterystyka-rynku/5317,2012.html. (03.03.2015).

${ }^{17}$ Own calculations based on data published by the companies.

${ }^{18}$ Own calculations based on data published by the banks; the share is measured by the assets, excluding cooperative banks. 
Table 1 also shows sectors which are highly integrated, but the level of their concentration is medium or low. This refers to agriculture production, food industry, water supply, chemical industry and road transport. All these sectors remain either important, indispensable elements of the economy (road transport, chemical industry) or they are necessary to satisfy subsistence needs of citizens (agriculture, food industry, water supply and healthcare). The road transport is dominant in Poland, and it would be relatively difficult to replace it. $75 \%$ of cargo is transported in this way ${ }^{19}$. However, this is a quite dispersed sector (Majecka, 2012, p. 154), so it cannot be considered strategic to the national security. A similar situation refers to the chemical industry whose products are fundamental for agriculture and other industries. However, this sector is highly deconcentrated (Sektor chemiczny ..., 2011, p. 55). Sectors which are vital for satisfying subsistence needs of citizens, such as agriculture, food industry, water supply or healthcare are also deconcentrated. Each of these sectors comprises a large number of firms. A potential disruption of even a part of them will not generate any significant threats to the citizens because in such a case extra business operations would be taken over by other existing companies. Moreover, in some sectors there is a possibility of quick supplementing by import activities. Therefore, these sectors cannot be considered strategic to the national security.

Hard coal mining is a separate issue. It a sector of a significant effect on the economy. In Poland, hard coal dominates in the consumption of energy with a share of $40 \%$ (Malec et al., 2014, p. 28). It is a primary fuel used in electricity production, and half of all energy units are power plants using coal. Mining is licensed and the sector is highly concentrated. CR(4) is 90\% and the largest producers are Kompania Węglowa (46\%), Jastrzębska Spółka Węglowa (18\%), Katowicki Holding Węglowy (16\%) and Bogdanka (10\%) (Malec, Kamiński, Warchoł, 2014, pp. 26-34). Nonetheless, importing coal is becoming more and more important. In 2013 import equaled to 10.8 tons, which constituted $14 \%$ of domestic mining (StalaSzlugaj, 2014, pp. 32-38). Therefore, there is a substitute for domestic coal which can be relatively easy to introduce and it is hard to consider the coal mined in Poland a strategic resource. However, it should be noticed that mining in Poland remains an important part of the economy, especially in the context of number of employees (there are 110,000 people employed in mines and the whole industry related to mining employs 400,000 people (Kasztelewicz, 2012, p. 13), and the territorial concentration of mining (Śląsk).

19 Data for 2013. Retrieved form http://stat.gov.pl/obszary-tematyczne/transport-ilacznosc/transport/przewozy-ladunkow-i-pasazerow-w-2013-r-,11,2.html (03.03.2015). 
Some researchers consider air and railway transportation as well as harbors and airports strategic to the national security. Nonetheless, it must be explained that harbors and airports play an infinitesimal role in domestic logistics. The share of cargo (in ton-kilometers) transported via air or railways equals $5 \%$ and $0.03 \%$ respectively ${ }^{20}$. However, these means of transport are important in case of a military threat when there is a need of fast and reliable shipment of military equipment. In Poland there are 14 civil airports, among which the largest one is Warsaw airport managed by P.P. Porty Lotnicze. Four harbors in Gdańsk, Gdynia, Szczecin and Świnoujście are managed by three companies - port authorities. The railway transportation does not dominate in the structure of cargo either. It's share (in ton-kilometers) is $15 \%{ }^{21}$. Similar to air transportation, railways can be important in case of military threats. The railways infrastructure in Poland is controlled by PKP holding which includes, inter alia, PKP Cargo and PKP Polskie Linie Kolejowe. HHI based on the weight of cargo was equal to 4,327 and CR(3) was $89,8 \%$ in 2010 . This shows that the concentration of this sector is very high (Raport $z$ badania..., 2012, pp. 77-79). Nonetheless, due to the above-mentioned insignificant role in the economy, the sectors cannot be considered strategic to the national security.

It is worth mentioning the sector of mining of non-ferrous metal ores, which is represented in Poland by KGHM. This sector, being a company at the same time, is sometimes considered strategic to the national security.

\section{State's Capital Control over Strategic Sectors - the Domestic Market}

The state's capital control over sectors of strategic importance to its security is the strongest and the most efficient tool of state's activity in this respect as well as carrying out the economic and security policy. Basing on the criteria defined above. i.e.:

- doing the business that directly satisfies the needs of the national security, or

- high degree of integration of a given sector with other sectors of the economy or with subsistence needs of the society, and simultaneously high degree of concentration of the sector,

20 Data for 2013. Retrieved form http://stat.gov.pl/obszary-tematyczne/transport-ilacznosc/transport/przewozy-ladunkow-i-pasazerow-w-2013-r-,11,2.html; (03.03.2015).

21 Data for 2013. Retrieved form http://stat.gov.pl/obszary-tematyczne/transport-ilacznosc/transport/przewozy-ladunkow-i-pasazerow-w-2013-r-,11,2.html; (03.03.2015). 
7 individual sectors which meet the terms were identified. These are:

- banknotes, documents and related IT production;

- extraction, transfer, distribution and storage of gaseous fuels;

- arms and ammunition production;

- extraction, transfer and storage of liquid fuels;

- production and supply of electric energy;

- banking;

- telecommunication.

The Treasury is a shareholder in each of the above sectors, except from telecommunication. The degree of the Treasury's capital control differs across the sectors and companies. The highest degree of control refers to production of banknotes, documents and related IT. The business is run by one company, i.e. PWPW, which is a one-man Treasury company. It should be noticed that in Poland there is no legislation that regulates the operations of a producer of banknotes and documents. PWPW is not a legal or real (but stable) exclusive producer of banknotes or documents. Moreover, in Poland there is no institution responsible for selection of security features in documents and there is no legal act or a state policy defining standards of protection of different types of documents. A lack of such a systematic regulation is a weakness, which is pointed out by experts (e.g. Goc, 2009, pp. 7-12; Lewandowski, 2014b, pp. 37-38).

Extraction, transfer, distribution and storage of gaseous fuels is also a sector which is controlled by the state. The business operations of extraction and distribution are dominated by a public company PGNiG, in which the Treasury holds $72 \%$. So the company is practically controlled by the Treasury. The articles of association provide for special rights of the Treasury. These are in particular:

1) a required consent of the Minister of Treasury in order to:

a) change significant provisions of commercial contracts referring to natural gas import or conclude new such contracts,

b) commence strategic investment projects or participate in investment projects that temporarily or permanently worsen the economic situation of the company but ensure the energetic security of Poland,

2) rights of appointing and dismissing one member of the Supervisory Board as long as the Treasury remains a shareholder of the company (which does not limit the ordinary competences, in this respect, coming from voting rights on the general meeting),

3 ) an increased threshold of the required majority of voting rights (to the level of 4/5) for given resolutions of the general meeting in case the Treasury holds less than $51 \%$ in the equity. 
According to legal regulations, natural gas transfer is monopolized by Gaz-System, which plays the role of a network transfer operator. Since December 2008 Gas-System has controlled Polskie LNG, a company which was set up in order to build and then operate a terminal of liquefied natural gas (LNG). Thanks to the terminal, it will be possible to diversify the directions of gas supply, which will improve the energetic security of Poland. The system of transit gas pipelines is controlled by EuRoPol Gaz, which is the owner of the Polish part of the Yamal-Europe Transit Pipelines System. PGNiG holds $48 \%$ in EuRoPol, a Russian company OAO Gazprom holds another $48 \%$ and Gas-Trading controls $4 \%$. The shareholders of GasTrading are: PGNiG (43,41\%), Bartimpex $(36,17 \%$; controlled by the Gudzowaty family), Russian Gazprom Eksport (15,88\%), Węglokoks (2,27\%, controlled by the Treasury) and Wintershall (2,27\%; a German company belonging to BASF, and closely cooperating with Gazprom). Consequently, the Treasury indirectly holds $45,68 \%$ in the equity of GasTrading (via PGNiG and Węglokoks). Such an equity structure (lack of a majority directly or indirectly held by the Treasury) together with lack of majority in EuRoPol Gaz does not ensure a stable state control over the company. This difficult situation implicated an attempt of a decisionmaking paralysis between 2013 and 2014 (Kublik, 2014). According to the articles of association of EuRoPol Gaz, PGNiG is entitled, after the Treasury's acceptance, to recommend two of its representatives to the management board. OAO Gazprom has a similar right.

Another sector which is controlled, in terms of ownership, by the state is arms and ammunition industry. In consequence of consolidation in 2014 and 2015 most of companies in this sector have been allocated to the holding of Polska Grupa Zbrojeniowa (PGZ). The Treasury holds there directly 52\% and Agencja Rozwoju Przemysłu, directly controlled by the Treasury, holds the remaining $48 \%$. So, in practice, PGZ is fully controlled by the state. The articles of association provide special rights for the Ministry of Defense, whose positive opinion is required in case of selected legal actions of the company. It significantly increases the range of the state's control over the company.

The sector of extraction, transfer and storage of liquid fuels is also controlled by the state. Extraction of liquid fuels is a duopoly market on which Orlen controls $62 \%$ and the remaining $38 \%$ belongs to Lotos. The subsector of wholesale distribution of liquid fuels is also dominated $(75 \%)$ by these two companies. In publicly traded Orlen, the Treasury holds $28 \%$ of shares and it is the largest shareholder. According to the articles of association, voting rights of shareholders other than the Treasury are limited to $10 \%$ regardless of the fraction possessed. It is an instrument which strengthens 
the position of the Treasury as a shareholder in Orlen. Moreover, the Treasury has the right to appoint and dismiss one member of the supervisory board as long as the Treasury remains Orlen's shareholder. This special right does not limit the regular right of the Treasury, which results from the quantity of votes on the general meeting. Selected resolutions of the supervisory board require a consent (a vote 'in favor of') of the member appointed by the Treasury. In Lotos, which is also listed on the Warsaw Stock Exchange, the Treasury holds 53\%. The special right of the Treasury covers the right of appointing and dismissing one member of the supervisory board (which does not limit the regular right of the Treasury, which results from the number of votes on the general meeting) and a limitation of voting rights (to 10\%) of shareholders other than the Treasury.

Production and supply of electric energy is a strategic sector in which the state is an active shareholder. The Treasury holds the majority of shares $(58 \%)$ in the largest producer of energy in Poland, PGE, which controls $38 \%$ of the market. In the second largest energy producer, Tauron (15\% of the market), the Treasury holds $30 \%$ and $\mathrm{KGHM}^{22}$ (controlled by the state) $-10 \%$. In the fourth largest producer, Enea (8\%), the Treasury holds 52\%. The market of sales and distribution of energy is dominated also by the above-mentioned companies together with Energa (16\% of the distribution market). In Energa the Treasury holds 52\% in equity, which gives $64 \%$ in votes. The Treasury, as a shareholder of the discussed firms, has, on the grounds of articles of association, individual rights referring to appointing and dismissing a specified number of members of the supervisory boards. Moreover, the number of voting rights of shareholders other than the Treasury is limited (to 10\%) regardless of the quantity of shares (PGE, Energa and Tauron) and there is an increased threshold of the required majority of voting rights (to the level of 4/5) for some resolutions made by the general meeting (Enea). All the mentioned companies from the energy sector are publicly traded. The total share of them on the markets of energy producing and distributing is $64 \%$ and $93 \%$ respectively. The transfer of energy (without distribution) is monopolized by one operator, PSE. According to article 9k of the Energy law, the operator of the transfer system acts as a joint stock company whose sole shareholder is the Treasury. Therefore, it can be concluded that the analyzed sector is controlled by the state.

In the banking industry the Treasury does not possess a significant stake. The Treasury is a dominating investor $(31 \%)$ in PKO BP, which

\footnotetext{
${ }^{22}$ The Treasury holds $32 \%$ in KGHM being the largest shareholder of this company.
} 
controls $18 \%$ of the deposits market ${ }^{23}$. The Treasury is also the sole owner of Bank Gospodarstwa Krajowego, but the bank is not a commercial one. One should also mention BOŚ Bank (1.5\% in deposits market), which is mainly controlled by a government institution, Narodowy Fundusz Ochrony Środowiska i Gospodarki Wodnej (57\%). The banking sector in Poland is dominated by foreign investors.

The telecommunication sector is practically almost free of the state equity ownership. The only exception is the subsector of fiber-optic backbone networks where two companies operate and are indirectly controlled by the state. These are Exatel and TK Telekom, which together control about 24\% of the domestic market of fiber-optic backbone networks. The telecommunication sector is the weakest controlled (in terms of equity) sector of strategic importance to the national security.

Figure 1 shows the market share of companies controlled by the Treasury in sectors which are strategically important to the national security.

Figure 1. Market share of companies controlled by the Treasury in sectors of strategic importance to the national security
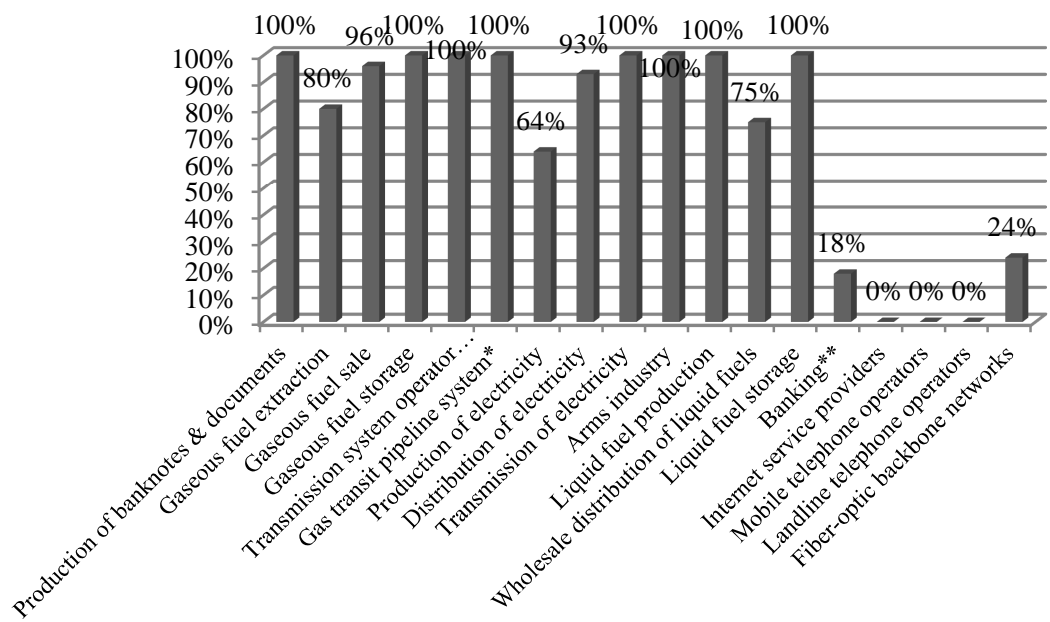

\footnotetext{
* Under condition that the Treasury controls EuRoPol Gaz

*** It refers to the deposits market
}

Source: own compilation.

${ }^{23}$ Data for the $3^{\text {rd }}$ quarter of 2014. Retrieved form http://www.pkobp.pl/grupa-pkobanku-polskiego/relacje-inwestorskie/raporty-finansowe/\#\&category=1862\&subcategory=4 1829 (06.03.2015). 
The presented graph shows that the state controls almost all the sectors which are strategically important to the national security. The only two exceptions are banking, where the share is only $18 \%$, and telecommunication, where the state possesses no control in subsectors of telephony or Internet and (indirectly) controls $24 \%$ of fiber-optic networks.

Diagram 1 shows the identified companies controlled by the state and assigns them to previously defined criteria of being strategically important to the national security. According to the presented analysis and the diagram, it can be concluded that the first criterion (business directly satisfying the needs of the national security) is met only by two companies: PGZ and PWPW. The second criterion (high degree of integration and high degree of concentration) is met also by PWPW as well as PKO BP, BGK, BOŚ, PGNiG, Gaz-System, EuRoPol Gaz, PERN, PGE, Energa, Enea, Tauron, PSE, Orlen, Lotos, Exatel and TK Telekom.

Diagram 1. Controlled by the Treasury companies belonging to sectors of strategic importance to the national security

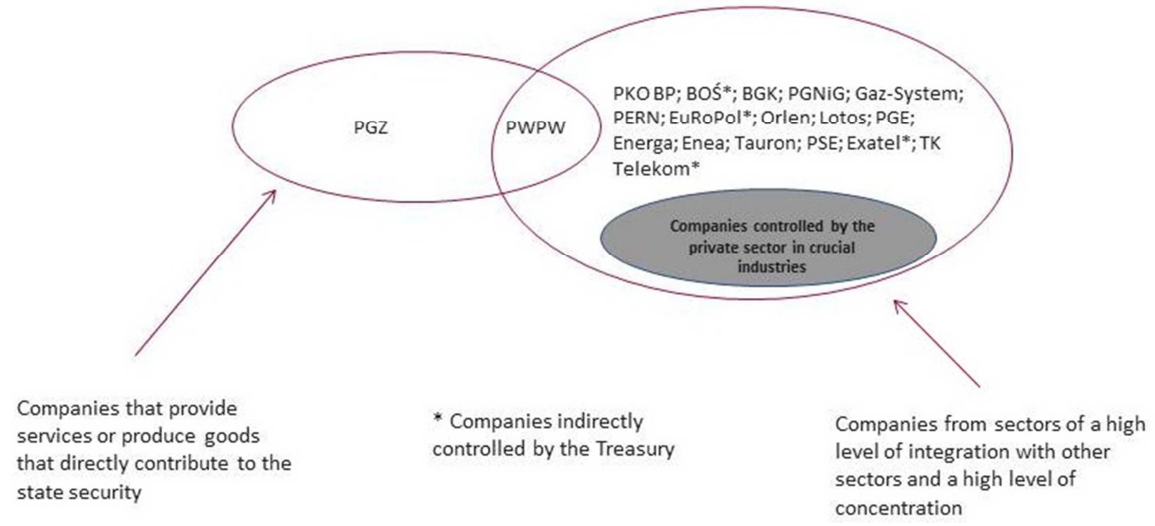

Source: own compilation.

\section{State Ownership in Strategic Sectors - Foreign Selected Markets}

State ownership in strategic sectors is not a specific attribute of the Polish economy. Equity ownership, as an instrument of the national security management, is a quite spread phenomenon, also present in European countries possessing well established free market economies. A good example of that is Germany, where the state ownership covers (Die Beteiligungen..., 2013): 
- finance and banking in particular (e.g. Kreditanstalt für Wiederaufbau, $80 \%$ in equity),

- energy and mining (eg. Energiewerke Nord, 51\% in equity; Lausitzer und Mitteldeutsche Bergbau-Verwaltungsgesellschaft, 100\% in equity),

- transportation (eg. Deutsche Bahn, 100\% in equity; some harbors and airports),

- telecommunication (eg. Deutsche Telekom, $15 \%$ in equity),

- banknotes and documents production (Bundesdruckerei, 100\% in equity).

In Germany the state controls about 700 companies. In France the state controls selected parts of the economy via a specialized agency APF (the state is a shareholder of 74 companies through APF), but additionally the state is directly involved in ownership in a banking industry and mutual funds. The analysis of the French engagement leads to the conclusion that the state remains an investor in following sectors ${ }^{24}$ :

- finance and banking,

- energy,

- arms and ammunition industry,

- aerospace industry,

- telecommunication,

- transportation,

- banknotes and documents production.

The above examples from Germany and France indicate that the state's presence in ownership structures of companies playing a significant role in national security is not a special and unique case. It is a solution which is widely used and it is justified by the national security protection. Therefore, it confirms the conclusion that the state ownership in the discussed sectors is not only necessary but also effective since it is present in countries of well established free market economies.

\section{Conclusions}

Using appropriate criteria, sectors of strategic importance to the national security have been identified in this paper. The sectors cover:

- banknotes, documents and related IT production;

- extraction, transfer, distribution and storage of gaseous fuels;

${ }^{24}$ Retrieved from http://www.economie.gouv.fr/files/files/directions_services/agenceparticipations-etat/Documents/Rapports-de-1-Etat-actionnaire/2014/Rapport_APE.pdf (07.03.2015). 
- arms and ammunition production;

- extraction, transfer and storage of liquid fuels;

- production and supply of electric energy;

- banking;

- telecommunication.

In the above sectors, there are companies that have strategic importance to the national security, i.e. companies whose distorted business operations would significantly violate the national security. The Polish state is a considerable shareholder in all the sectors except for telecommunication. Moreover, except for telecommunication and banking, the Polish state practically controls all the sectors of strategic importance to the national security. Such an active role of the state in the economy is also often accepted in other countries. Good examples of them are Germany and France, whose governments hold shares in strategic sectors similar to those identified in Poland, including the telecommunication sector, though.

However, the state's management of the identified part of the economy is not integrated in Poland. The sectors are managed through the branch perspective (for instance, industry policies or sector strategies) or through the individual functions of the security (e.g. CI, military security, energy security etc.). There is no holistic vision of the state-controlled assets of the strategic importance to the national security. Such a holistic perspective should cover identifying the aforesaid assets (in the form of individual firms), preparing coherent instruments of their protection (e.g. against hostile takeovers) and preparing development programs that are necessary in order to realize the key interest of the state, including the national security interests.

\section{References}

Amsden, A. (2001). The Rise of the Rest: Challenges to the West from Late Industrializing Economies. New York: Oxford University Press.

Barney, J., \& Zajac, E. (1994). Competitive Organizational Behavior: Toward an Organizationally Based Theory of Competitive Advantage, Strategic Management Journal, 15.

Die Beteiligungen des Bundes, Bunderministerium der Finanzen (2013). Retrieved form http://www.bundesfinanzministerium.de/Content/DE/Standardartikel/ Themen/Bundesvermoegen/Privatisierungs_und_Beteiligungspolitik/Beteiligu ngen_des_Bundes/Beteiligungsbericht-Anlage-2013.pdf?__blob=publicationFi le\&v $=1(07.03 .2015)$.

Dziawgo, D. (2007). Rynek finansowy. Istota - instrumenty - funkcjonowanie, Warszawa: Stowarzyszenie księgowych w Polsce. 
Flak, K. (2014). Zamówienia publiczne w dziedzinach obronności i bezpieczeństwa - dyrektywa 2009/81/WE i jej implementacja do polskiego prawa krajowego. Bezpieczeństwo. Teoria i Praktyka, 1(XIV).

Goc, M. (2009). O potrzebie uregulowań prawno-organizacyjnych problematyki dokumentów publicznych. Człowiek i Dokumenty, 13.

Hall, P., \& Soskice D. (2001). An Introduction to Varieties of Capitalism. In W. P. Hall \& D. Soskice (Eds.). Varieties of Capitalism: The Institutional Foundations of Comparative Advantage. New York: Oxford University Press.

Kahn, A. E. (1988). The Economics of Regulation: Principles and Institutions, Vol. I. Cambridge, MA, London: The MIT Press.

Kasztelewicz, Z. (2012). Blaski i cienie górnictwa węglowego w Polsce. Polityka Energetyczna, 15(4).

Kawalec, S., \& Gozdek, M. (2013). Pożądana struktura sektora bankowego w Polsce. Biuletyn PTE, 1(60).

Kitler, W. (2011). Bezpieczeństwo narodowe RP. Podstawowe kategorie, uwarunkowania, system. Warszawa: AON.

Knurowska, I. (2000). Ochrona przed wrogiem przejęciem. Dom Wydawniczy Ostoja.

Kosikowski, C. (2007). Publiczne prawo gospodarcze Polski i Unii Europejskiej. Warszawa.

Kublik, A. (2014). PGNiG nie dało Gazpromowi sparaliżować EuRoPol Gazu, Gazeta Wyborcza, January 21st.

Łagowska, K. (2012). Działalność gospodarcza jako forma reglamentacji gospodarczej. In M. Sadowski \& P. Szymaniec (Eds.). Prace z teorii i historii prawa oraz administracji publicznej. Wrocław: Wydział Prawa, Administracji i Ekonomii Uniwersytetu Wrocławskiego.

Lewandowski, R. (2014a). Budowa potencjału gospodarczego w oparciu o strategię narodowych czempionów - studium przypadku PWPW S.A. In D. Zarzecki (Ed.). Efektywność inwestycji i wycena przedsiębiorstw. Szczecin: Wydawnictwo Naukowe US.

Lewandowski, R. (2014b). Wiarygodność procesów identyfikacji i transakcji a system bezpieczeństwa państwa. Bezpieczeństwo. Teoria i Praktyka, 1(XIV).

Majecka, B. (2012). Uwarunkowania zachowań przedsiębiorstw transportu samochodowego na rynku przewozów rzeczy. Zeszyty Naukowe Uniwersytetu Gdańskiego. Studia i Materiały Instytutu Transportu i Handlu Morskiego, 9.

Malec, M., Kamiński, J., \& Warchoł, R. (2014). Przegląd aktualnej struktury wydobycia w krajowym sektorze górnictwa węgla kamiennego. Zeszyty Naukowe Instytutu Gospodarki Surowcami Mineralnymi i Energia PAN, 87.

Mathews, J. (2002). The Origins and Dynamics of Taiwan's R\&D Consortia. Research Policy, 31.

Nagaj, R. (2012). Przesłanki regulacji rynków w świetle teorii wyboru publicznego. Studia i Prace Wydziału Nauk Ekonomicznych i Zarzadzania, 27.

Olszewski, L. (2012). Strategiczne sektory w rozwoju współczesnej gospodarki narodowej. In J. Blicharz (Ed.). Prawne aspekty prywatyzacji. Prawnicza i Ekonomiczna Biblioteka Cyfrowa. 
O’Sullivan, M. (2000). Innovative Enterprise and Corporate Governance. Cambridge Journal of Economics, 24.

Raport o stanie rynku telekomunikacyjnego w Polsce w 2013 r. (2014). Warszawa: Prezes Urzędu Komunikacji Elektronicznej.

Raport z badania krajowego rynku transportu towarów (ze szczególnym uwzględnieniem transportu towarów koleją) (2012). Warszawa: UOKiK.

Samaryna, H. (2010). Deflacja w Japonii. Warszawa: PWE.

Stala-Szlugaj, K. (2014). Import węgla kamiennego do Polski. Przeglad Górniczy, 5.

Strategia Bezpieczeństwa Narodowego RP (2014). Warszawa.

Strategia i model biznesowy Grupy ENERGA (2012).

Sektor chemiczny w czasie i przestrzeni. Ocena standingu adaptacyjnego sektora, Grupa Doradców Biznesowych BAA Polska (2011). Warszawa. Retrieved form www.bcc.org.pl/blz/pliki/raporty/CHEMIA_XI_2011.pdf (03.03.2015).

Sudak, I. (2015). Rząd chce ręcznie sterować zagranicznymi inwestycjami w Polsce, Gazeta Wyborcza, $24^{\text {th }}$ February.

Zahariadis, N. (1998). The Rise and Fall of British State Ownership: Political Pressure or Economic Reality?. Comperative Politics, 31(4). 